\title{
CHANGES IN FOREST FLOOR AND TREE VEGETATION IN THE LEVEL II MONITORING PLOT IN VALGUNDE PARISH
}

\author{
Guna Petaja, Ainārs Lupiḳis, Andis Lazdin̄̌s \\ Latvian State Forest Research Institute 'Silava' \\ guna.petaja@silava.lv
}

\begin{abstract}
The objective of the research was to characterize the qualitative and quantitative changes in ground and tree vegetation within 10 years since the beginning of observations at Level II forest monitoring plot in Valgunde. Tree height, diameter, stem volume, radial increment, crown condition and cone yield were determined, as well as crown projective cover of each plant species was estimated. To study bioindication, the average Ellenberg's and Düll's indicator values for the monitoring plot were estimated. Species composition in the Level II monitoring plot in Valgunde is typical for Myrtillosa forest type - there is a distinct moss layer, in which Hylocomium splendens and Pleurozium schreberi predominate, and Vaccinium myrtillus is the most common in the herb layer. Shrub layer mainly consists of spruce seedlings, and the tree layer - of Scots pine. Changes in vegetation over 10 years are insignificant. It can be explained with no forest management activities occurring within the observation plot, such as logging or fertilization, and it may take a longer time to observe significant changes. Tree stand indicators correspond to the average in Latvia in Myrtillosa type forests, but the tree volume is higher in Valgunde monitoring plot.
\end{abstract}

Key words: Myrtillosa, Level II monitoring, vegetation, Ellenberg's indicator.

\section{Introduction}

Forests in Latvia cover 3.2 million hectares of land or $52 \%$ of the country's territory and standing wood volume is 631 million $\mathrm{m}^{3}$ (Zemkopības Ministrija, 2017). The growth of trees and crown condition are key ecological parameters of forests, and thus highly important indicators of forest condition. Ground vegetation is another important component of forest ecosystems. A long-term study of vegetation changes helps to provide information on the status of forest organisms and environmental variables. Forests are greatly dependent on climate and numerous studies show that any change in abiotic factors can lead to considerable changes in biodiversity (Nordin et al., 2005; Lindner et al., 2010; Bell et al., 2016). Growth and composition of vegetation are affected by many climatic factors - precipitation, light, temperature, relative humidity and wind. The possible negative effects on forests caused by climate change are spread of diseases and disappearance of native species, loss of needles or leaves, deforestation and soil degradation as a result of changes in $\mathrm{pH}$, organic content and bacteria content. The overstorey trees have an impact on the ground vegetation through shading and regulation of the nutrient levels and moisture (Kuusipalo, 1985; Barbier et al., 2008).

During the last century the average annual temperature in Latvia has risen by $0.8-1.4{ }^{\circ} \mathrm{C}$, the amount of precipitation has increased, but periods of snow and ice cover are shorter. There is a slight increase in forest fire danger and net primary production, as well as considerable increase in frost events after budburst and spruce bark beetle attacks (Bergh et al., 2010; Camia, Amatulli, \& San-MiguelAyanz, 2008; EEA, 2005). The effect of winterspring temperature on tree-ring width of European beech (Fagus sylvatica) and European larch (Larix decidua) has lost significance, suggesting a successful acclimation of stands growing northwards from their natural distribution in western Latvia (Jansons et al., 2015a). Studies of tree-ring width and mean area of early-wood vessel lumen of red oak (Quercus rubra) suggest that climate warming would increase vessel lumen area and result in a risk of embolism and xylem dysfunction (Matisons et al., 2015). An increase in temperature burdens formation of tree-rings of hybrid poplars (Populus balsamifera $\times P$. laurifolia) and hybrid aspens (Populus tremuloides $\times$ P. tremula) (Šēnhofa et al., 2016). The influence of climatic factors on Scots pine height increment has changed. In western Latvia, the effect of temperature in preceding September and November has become significant, whereas in east the effect of temperature in October has become the main factor affecting height increment (Jansons et al., 2015b). Due to climate change, the influence of precipitation amount on radial growth of Scots pine can increase, but the influence of mean air temperatures in winter will decrease, and Scots pine may become precipitation-amount limited in Latvia (Elferts \& Jansons, 2012).

ICP forests (the International Co-operative Programme on Assessment and Monitoring of Air Pollution Effects on Forests), in cooperation with the European Commission, monitors the forest condition in Europe using two different monitoring intensity levels. The Level I monitoring is based on around 6000 observation plots on a systematic transnational grid of $16 \times 16 \mathrm{~km}$ throughout Europe (Bārdule et al., 2009). An overall estimation of tree health condition is done there. The Level II monitoring in Europe was started in 1994 with an aim of carrying out an investigation on the effect of atmospheric deposition 
and other stress factors on forest ecosystem (Bārdule et al., 2010). The Level II intensive monitoring comprises around 500 plots in selected forest ecosystems across Europe. In-depth investigation of forest ecosystem is carried out in order to get a more complete picture of influence of air pollution and other stress factors on forest ecosystems. Currently, the program has set the objective to contribute to such important environmental issues as climate change and biodiversity as well. Its data is required for a range of institutions and conventions (MCPFE, CLRTAP etc.).

National forest monitoring in Latvia is a monitoring, analysis and forecasting system of forest resources and environmental status, where scientific methods are used. It includes monitoring of forest resources, Level I and Level II air pollution influence assessment, as well as scientific monitoring of forest pests and diseases. Information on the first level assessment of air pollution influence monitoring is obtained by carrying out annual observations in 115 observation plots on a systematic transnational grid, as well as in observation plots in grid of $16 \times 16 \mathrm{~km}$ (Libiete et al., 2010).

The objective of the research is to characterize qualitative and quantitative changes in the forest ground and tree vegetation within 10 years since the beginning of observations in Valgunde plot. The general hypothesis is that changes in the forest ground vegetation are insignificant, whereas tree growth (increment) corresponds with the average indicators in similar growth conditions.

\section{Materials and Methods}

The Level II observation plot in Valgunde is rectangular $(40 \times 60 \mathrm{~m})$ with a total area of $2400 \mathrm{~m}^{2}$. The plot is divided into sections of $100 \mathrm{~m}$ in order to characterize the ground vegetation. In order to observe changes in species cover, vegetation was assessed in 2 ways: (1) within an area of $400 \mathrm{~m}^{2}$ by dividing each rectangular plot $(20 \times 5 \mathrm{~m})$ in four smaller squares $5 \times 5 \mathrm{~m}$ (16 squares in total), considered as base units for vegetation assessment; (2) within an area of $26 \mathrm{~m}^{2}$, placing six $1 \times 1 \mathrm{~m}$ squares in each rectangular observation plot and taking them as basic units. Two additional squares are placed between rectangular plots. Vegetation is made up of 4 layers: trees, shrubs, herbs and mosses. Trees with height less than $0.8 \mathrm{~m}$ are counted as herbs. In this study, vegetation was inventoried over the period $2004-2012$.

In surrounding areas, a $10 \mathrm{~m}$ wide unrestricted buffer zone has been established where samples are taken for several monitoring subprograms, such as precipitation, tree increment etc. Next to the tree stand observation plot, a 40 x $30 \mathrm{~m}$ large soil observation plot has been established. According to national soil classification, soil in terrain elevations of Valgunde plot is a typical podzolic sandy soil, but in declines - peaty podzolic gley soil. According to the FAO classification system, the soil type corresponds to Haplic Arenosols. It is coarse-textured, weakly developed soil.

Ellenberg's indicator values (EIVs) are commonly applied in Europe as bioindicators of primary environmental traits: light, temperature, continentality, moisture, soil $\mathrm{pH}$ and fertility (Szymura et al., 2014). Ellenberg's indicator values range from 1 to 9 (Table 1). Ellenberg's indicator was initially developed for herb species in the United Kingdom, but it can be extended to other regions.

The value of a specific environmental factor at a specific site is estimated by using arithmetic means of the indicator values for this factor of all species (Ter Braak \& Barendregt, 1986). EIVs are calculated by weighted average formula (Sürmen et al., 2014):

$$
\text { weighted average }=\frac{\sum_{i=1}^{n}\left(r_{i j} * x_{1}\right)}{\sum_{i=1}^{n} r_{i j}}
$$

where $r_{i j}$ is the response of species $i$ in sample plot $j, x_{i}$ is the indicator value newline of species $i$.

EIVs used in this study are approximated for Russian Federation (Czerepanov, 1995; Ignatov \& Ignatova, 2003). Similarly as Ellenberg's indicator is used to calculate environmental factors of herbs, Düll's indicator is used for bryophytes. In this study, the mean EIVs and Düll's indicator values were calculated over years 2004, 2009 and 2012.

\section{Ellenberg's indicator values for main environmental factors (Nuamah, 2017)}

\begin{tabular}{|l|l|l|}
\hline \multicolumn{1}{|c|}{ Environmental Factor } & Symbol & \multicolumn{1}{c|}{ Indicator value } \\
\hline Light & L & $1=$ deep shade, $5=$ semi-shade, $9=$ full light \\
\hline Temperature & T & $1=$ alpine-subnival, $5=$ submontane-temperate, $9=$ Mediterranean \\
\hline Continentality & K & $1=$ euoceanic, $5=$ intermediate, $9=$ eucontinental \\
\hline Moisture & F & $1=$ strong soil dryness, $5=$ moist, $9=$ wet, $10=$ aquatic, $12=$ underwater \\
\hline Soil reaction $(\mathrm{pH})$ & R & $1=$ extremely acidic, $5=$ mildly acidic, $9=$ alkaline \\
\hline
\end{tabular}


Tree growth measurements were carried out according to internationally accepted methodology (ICP Forests Manual on Estimation of Growth and Yield). Tree diameter was measured at $1.3 \mathrm{~m}$ height. Tree growth measurements (height, diameter and crown projection) were done for 60 selected trees. Tree height measuring sites were marked with stakes at a $20 \mathrm{~m}$ distance from the particular tree. Tree crown projections were estimated in four directions $-\mathrm{N}, \mathrm{E}$, S, W.

In order to measure tree radial increment, 15 manually readable tree increment bands were set up. Bands were placed randomly throughout the observation plot, including trees of Kraft's classes 1, 2 and 3. Measurements of tree increment bands were read systematically once in every 2 weeks.

To estimate tree canopy status 60 trees of Kraft's classes 1, 2 and 3 were randomly selected by dividing observation plot into 24 squares and by selection of 2 to 3 trees of each Kraft's class in every square. Defoliation in the first third or the whole canopy, dechromation, tree damages and cone yield of the observation plot trees were also measured and Kraft's class of the tree was determined. Defoliation is a loss of needles/leaves within the assessed canopy and it is the main indicator of tree health status. It is determined irrespective of the cause. Defoliation is evaluated in $5 \%$ classes. These classes are: 0 (no defoliation); 5 (defoliation $>0-5 \%), 10$ (defoliation $>5-10 \%$ ) etc. Cone yield is divided in 3 classes ( 1 - no yield, $2-$ medium yield, 3 - good yield). Splitting of class 1 in subclasses (1.1 - cones are not observed, 1.2 - only a few cones have been observed) was started from 2014.

\section{Results and Discussion}

Vegetation in the observation plot is typical for mesotrophic pine forests - it has a distinct moss content and a herb layer. A few Norway spruce and oak seedlings $(<50 \mathrm{~cm})$ are found in shrub and herb layer, but the tree layer mainly consists of Scots pine. The average projection of shrubs is the smallest, comparing with tree and herb projection: in 2004 it was $8.26 \%$, in 2009 decreased to $4.06 \%$, but in 2012 it slightly increased up to $4.5 \%$. The average herb projection in 2004 was $55 \%$, in 2009 it was $57 \%$, but it $2012-65.63 \%$. Tree crown projection has decreased in the following years. In 2004 it was $64.06 \%$, in $2009-47 \%$ and in $2012-45 \%$. Oaks were found only as young seedlings with small projection area during the entire observation period. The average moss projection slightly increased in years 2009 and 2012 and was $87 \%$ and $88 \%$, respectively.

By further analysis, in total 21 plant species were identified in 2004. Five species from those found in the monitoring plot are also common in other parts of Europe: blueberry (Vaccinium myrtillus L.); bog bilberry (Vaccinium uliginosum L.); lingonberry (Vaccinium vitis-idaea L.); the small cow-wheat (Melampyrum sylvaticum L.); Scotch heather (Calluna vulgaris L.). Ten moss species were found, from which Pleurozium schreberi (39.4\%) and Hylocomium splendens $(42.4 \%)$ were the most common. Both moss species were also predominant in the following years and their projections slightly increased. Other identified moss species were Dicranum polysetum Sw., Aulacomnium palustre (Hedw.) Schwaegr., Ptilium crista-castrensis (Hedw.) De Not., Brachythecium oedipodium (Mitt.) Jaeg, Hypnum cupressiforme, Pohlia nutans (Hedw.) Lindb., Polytrichum juniperinum Hedw. Dicranum scoparium Hedw. was very rare and did not fit into the $100 \%$ scale with one decimal in $100 \mathrm{~m}^{2}$ observation plots. Pohlia nutans (Hedw.) Lindb and Polytrichum juniperinum Hedw. were not observed in the following years, comparing with 2004. Hypnum cupressiforme was not observed in 2009, but was observed again in 2012 .

10 species were found in herb layer, from which Vaccinium myrtillus (45.6\%) predominated. Other species were Calluna vulgaris (L.) Hull., Festuca ovina L., Goodyera repens (L.) R. Br., Melampyrum pratense L., Picea abies (L.) H. Karst., Quercus robur L., Scorzonera humilis L., Vaccinium myrtillus L., Vaccinium uliginosum L. and Vaccinium vitis - idaea L. Tree species found in the herb layer were Quercus robur L. and Picea abies (L.) H. Karst. The most common herb species in the following years was the same as in 2004 - blueberry Vaccinium myrtillus L. Festuca ovina L. was not observed in the herb layer in the following years. In 2009, three new species were observed - Dryopteris carthusiana (Vill.) H.P. Fuchs (0.01\%), Luzula pilosa (L.) Willd. (0.03\%) and Melampyrum sylvaticum L. (5.91\%). In 2012, two previously unobserved species were found Maianthemum bifolium and Plantago major. Their projection was below $0.01 \%$.

In 2004, there were only 3 species in the shrub layer - Picea abies (L.) H. Karst., Quercus robur L. and Vaccinium uliginosum L., and the projection was mostly formed of Norway spruce branches. In the following years, the shrub layer consisted only of Norway spruce.

Overall changes in vegetation are negligible. Presence and absence of some species with very small projections over time can be explained by methodological shortcomings rather than actual changes in species composition. No management activities, such as logging operations or fertilization, were carried out within the monitoring plot. Studies on short term responses to logging have shown that mosses and herbs are mostly affected negatively (Hannerz \& Hånell, 1997; Roberts \& Zhu, 2002; Fenton et al., 
Mean EIVs for Valgunde observation plot over period 2004 - 2012

\begin{tabular}{|l|c|c|c|}
\hline \multirow{2}{*}{\multicolumn{1}{|c|}{ Parameter }} & \multicolumn{2}{c|}{ Year } \\
\cline { 2 - 4 } & 2004 & 2009 & 2012 \\
\hline Light (L) & 5.0 & 5.0 & 5.0 \\
\hline Temperature (T) & 3.2 & 4.1 & 3.9 \\
\hline Continentality (K) & 5.0 & 5.0 & 3.9 \\
\hline Moisture (F) & 4.0 & 4.6 & 4.4 \\
\hline Reaction (R) & 2.0 & 2.0 & 2.0 \\
\hline Nitrogen content (N) & 2.7 & 3.4 & 2.6 \\
\hline
\end{tabular}

2003; Palviainen et al., 2005; Caners et al., 2013). The number and richness of forest floor vegetation species in European forests have changed over the last years due to wet and dry deposition of atmospheric nitrogen. Forest fertilization is another factor which increases soil nitrogen content. Such species as heather and lingonberry prefer nutrient-poor soils and are sensitive to nitrogen addition. Most of herb and moss species growing within the observation plot prefer soils poor in nitrogen. A drastic decrease in projection cover was not observed and it can be concluded that nitrogen deposition in Latvia is low. The increase in herb and moss projection cover could be a result of decrease in tree and shrub projection cover, thus allowing more sunlight to understorey vegetation. Herb species typical for Myrtillosa forest type are Vaccinum myrtillosa, Calamagrostis arundinacea, Vaccinium vitis-idaea, Maianthemum bifolium, Luzula pilosa, Solidago virgaurea L., Pteridium aquilinium (L.) Kuhn. and Orthilia secunda (L.). From mosses, the most common are Hylocomium splendens, Pleurozium schreberi, Dicranum polysetum, Dicranum scoparium and Ptilium crista-castrensis. Vaccinum myrtillosa and grasses are dominating in a typical Myrtillosa forest type. Nine of the above mentioned species were found in the monitoring plot. Grasses are not common in the observation plot.

In forestry, bioindication with the mean values of EIVshas beenused toassess the siteproductivity(Bergès et al., 2006) and to predict herb biomass production (Axmanová et al., 2012), water relationships in soils (Häring et al., 2013) and atmospheric deposition (Dobben et al., 1999). Some studies suggest that bioindication can perform better than instrumental measurements and predicts plant species occurrence more accurately (Dupré \& Diekmann, 1998; Jarvis et al., 2016). Plants used for bioindication are supposed to illustrate relevant environmental factors for them over time, while measurements provide snapshots and depend on choices of the researcher - sampling, analytical methods and choice of measured factors.

According to Ellenberg's scale indicator values obtained from our study (Table 2), herb layer vegetation grows in semi shade, temperature is between alpine and temperate, continentality value is intermediate, soil is moist and acidic, but nitrogen content is low. According to our calculated EIVs, the temperature increased in 2009 and slightly decreased in 2012; continentality value decreased by 1 in 2012. Moisture value also has slightly changed over years - in 2009 it increased by 0.6 and slightly decreased in 2012. Nitrogen content also increased in 2009 and decreased in 2012.

Our calculated mean Düll's indicator values for light, temperature, continentality and reaction only slightly differ from the mean EIVs, while the mean value for moisture is higher by 3 units (Table 3 ). There is no change in the mean Düll's indicator values over

Table 3

Mean Düll's indicator values for Valgunde observation plot over period 2004 - 2012

\begin{tabular}{|l|c|c|c|}
\hline \multirow{2}{*}{\multicolumn{1}{|c|}{ Parameter }} & \multicolumn{3}{|c|}{ Year } \\
\cline { 2 - 4 } & 2004 & 2009 & 2012 \\
\hline Light (L) & 6.0 & 6.0 & 6.0 \\
\hline Temperature (T) & 3.0 & 3.0 & 3.0 \\
\hline Continentality (K) & 6.0 & 6.0 & 6.0 \\
\hline Moisture (F) & 7.0 & 7.0 & 7.0 \\
\hline Reaction (F) & 3.0 & 3.0 & 3.0 \\
\hline
\end{tabular}


time. Düll's indicator values for nitrogen were not available.

Stem diameters were measured at breast height for 272 trees within the monitoring plot. The average height of trees was $24 \mathrm{~m}$ and average diameter was $21.5 \mathrm{~cm}$. The average diameter of pines is $21.5 \mathrm{~cm}$ and the average diameter of spruces $-10.3 \mathrm{~cm}$. The total basal area of a tree stand is $37.1 \mathrm{~m}^{2} \mathrm{ha}^{-1}$. The volume of growing trees is $417.3 \mathrm{~m}^{3} \mathrm{ha}^{-1}$. The average tree diameter in Myrtillosa type forests in Latvia is 30.9 $\mathrm{cm}$ and the average height of trees is $24.7 \mathrm{~m}$, dominant species is Scots pine and the average age of trees is 85 years. The average total basal area is $33.56 \mathrm{~m}^{2} \mathrm{ha}^{-1}$. The average tree count per ha is 936 . Our results are similar to those overall in Latvia. The age of the stand is 90 years. Site index of the stand in Valgunde is I.

The average tree crown defoliation in 2004 was $9.8 \%$. Undamaged and slightly damaged trees $(0-$ $10 \%$ ) were $23 \%$ of evaluated trees. Dechromation was not observed. In years $2009-2013$, the average defoliation did not change significantly. It was 15 $-20 \%$ on average, but did not exceed $30 \%$. There was a slight decrease in defoliation in 2010. As in previous years, also in 2015 severely damaged trees with defoliation more than $60 \%$ were not observed. The tree health condition in the observation plot is good with a predominance of slightly damaged trees. More than half of trees (63.3\%) belong to the defoliation class $5-15 \%$. Comparing with year 2014 , the proportion of trees with defoliation of $30 \%$ has increased from $3.3 \%$ to $11.7 \%$ in 2015 . At the same time, the amount of undamaged or slightly damaged trees has increased from $43.3 \%$ in year 2014 to $50 \%$ in year 2015. The average condition of defoliation has not changed and the condition of tree crowns has not worsened over years. There is a slight decrease in average defoliation. Data from 2004 to 2008 may not be taken into account because the evaluation of the tree crown condition was done by other experts. It has significantly affected comparability of results. Foliage dechromation was not observed until 2008, when 5\% dechromation was observed for one tree. The increase in dechromation was observed in 2014.

Cone yield has been estimated each year. Overall, during the past 11 years only minor changes in cone yield have been observed. In 2004, all 60 trees belonged to class 1 . The average cone yield increased from 1 in 2004 to 1.5 on average in 2005 . In 2006, there was a decrease to 1 again and in 2007 it decreased even more -0.5 on average. In 2008, it increased again to 1.3 , in 2009 - to 1.6 and in 2010 and 2011 remained approximately the same. In 2012, there was a slight decrease and in 2013 - an increase again. A slight decrease in 2015 was observed again. Trees with cone yield class 3 were observed in 2005 and afterwards from 2008. Cone yield is affected by flowering intensity and synchronicity as well as fertilization of strobiles. Those factors are affected both by heredity and environment (Sarvas, 1962; Dreimanis, 1973; Laura \& Bērziņa, 1978; Zviedre, 1985). Flowering intensity is determined by meteorological conditions during bud differentiation in the previous vegetation period (Zviedre, 1985), whereas female strobiles are negatively affected by frost in late spring (Neimane et al., 2014), as well as strong wind and rain or continuous draught. Accessibility of water and nutrients also is an influential factor (Karlsson \& Örlander, 2002).

Radial increment was determined for 272 trees over the period of 11 years $(2004-2015)$. The highest value of girth (perimeter) increment was 15.6 $\mathrm{cm}$ over 11 years and 1.42 each year. The average radial increment in 11 years was $1.11 \mathrm{~cm}$ and average annual increment was $0.1 \mathrm{~cm}$. Tree radial increment was affected by meteorological conditions, tree age and genetic factors (Puriņa et al., 2014). There was a reduction in tree radial increment over time. It is expected that tree annual radial increment will decrease even more in the next years due to increasing tree age and characteristics of the formation of the stem radial increment. Although radial increment of a tree is smaller, it does not mean it is growing slower - the increase in stem volume can be even bigger. It was found in the study that weather conditions can significantly affect measurement results due to swelling of bark after rainfalls.

\section{Conclusions}

1. There are no significant differences between tree stand indicators in Valgunde observation plot and in Myrtillosa type forests in Latvia on average, therefore the observation plot can be used to characterize processes in pine stands of respective forests.

2. The tree health condition in the observation plot is good with a predominance of slightly damaged trees. There is a slight decrease in average defoliation, but the overall condition of tree crowns has not worsened over years. Only minor changes in cone yield were observed.

3. Changes in the ground vegetation are insignificant and species composition is typical for Myrtillosa forest type.

4. According to Ellenberg's and Düll's indicators, vegetation grows in semi shade, temperature is between alpine and temperate, continentality value is intermediate, soil is moist and acidic, but nitrogen content is low.

\section{Acknowledgements}

The study was implemented within the scope of the National forest monitoring program with support of the Forest development fund. 


\section{References}

1. Axmanová, I., Tichý, L., Fajmonová, Z., Hájková, P., Hettenbergerová, E., Li, C.-F., Merunková, K., Nejezchlebová, M., Otýpková, Z., Vymazalová, M., \& Zelený, D. (2012). Estimation of herbaceous biomass from species composition and cover. Applied Vegetation Science, 15(4), 580 - 589. DOI: 10.1111/j.1654109X.2012.01191.x.

2. Barbier, S., Gosselin, F., \& Balandier, P. (2008). Influence of tree species on understory vegetation diversity and mechanisms involved-A critical review for temperate and boreal forests. Forest Ecology and Management, 254(1), 1 - 15. DOI: 10.1016/j.foreco.2007.09.038.

3. Bārdule, A., Bāders, E., Stola, J., \& Lazdiņš, A. (2009). Latvijas meža augsṇu īpašību raksturojums demontrācijas projekta BioSoil rezultātu skatījumā (Main characteristics of forest soils in Latvia according to results of the project BioSoil). Mežzinātne, 20 (53), 105 - 124. (in Latvian).

4. Bārdule, A., Lazdiņš, A., \& Bārdulis, A. (2010). Monitoring of deposition and soil solution in level ii forest monitoring plot in Latvia. In XXVI Nordic Hydrological Conference, 9 - 10 August, 2010 (p. 1). Riga: Latvian Environment, Geology and Meteorology centre (LEGMC).

5. Bell, F.W., Lamb, E.G., Sharma, M., Hunt, S., Anand, M., Dacosta, J., \& Newmaster, S.G. (2016). Relative influence of climate, soils, and disturbance on plant species richness in northern temperate and boreal forests. Forest Ecology and Management, 381, pp. 93 - 105. DOI: 10.1016/j.foreco.2016.07.016.

6. Bergès, L., Gégout, J.-C., \& Franc, A. (2006). Can understory vegetation accurately predict site index? A comparative study using floristic and abiotic indices in sessile oak (Quercus petraea Liebl.) stands in northern France. Annals of Forest Science, 63(1), 31 - 42. DOI: 10.1051/forest:2005091.

7. Bergh, J., Nilsson, U., Kjartansson B., \& Karlsson, M., (2010). Impact of climate change on the productivity of Silver birch, Norway spruce and Scots pine stands in Sweden with economic implications for timber production. Ecological Bulletins, 53 (16): 185 - 195.

8. Camia, A., Amatulli, G., \& San-Miguel-Ayanz, J. (2008). Past and future trends of forest fire danger in Europe. Ispra: JRC Scientific and Technical Reports. (EUR 23427 EN) Retrieved March 1, 2017, from: http://publications.jrc.ec.europa.eu/repository/handle/111111111/7973.

9. Caners, R.T., Ellen Macdonald, S., \& Belland, R.J. (2013). Linking the biological traits of boreal bryophytes to forest habitat change after partial harvesting. Forest Ecology and Management, 303, 184 - 194. DOI: 10.1139/B09-089.

10. Czerepanov, S.K. (1995). Сосудистые растения России и сопредельных государств (Vascular Plants of Russia and Adjacent States). Saint Petersburg: Мир и се-мья. (in Russian).

11. Dobben, H.F. van, Braak, C.J.F. ter, \& Dirkse, G.M. (1999). Undergrowth as a biomonitor for deposition of nitrogen and acidity in pine forest. Forest Ecology and Management, 114(1), 83 - 95. DOI: 10.1016/ S0378-1127(98)00383-1.

12. Dreimanis, A. (1973). Čiekuru ražas dažās priežu sēklu plantācijās (Cone crops in some pine seed plantations). Mežsaimniecība un Mežrūpniecība, 3: 13 - 16. (in Latvian).

13. Dupré, C., \& Diekmann, M. (1998). Prediction of Occurrence of Vascular Plants in Deciduous Forests of South Sweden by Means of Ellenberg Indicator Values. Applied Vegetation Science, 1(1), 139 - 150. DOI: $10.2307 / 1479092$.

14. European Environment Agency (2005). Vulnerability and adaptation to climate change in Europe. Louxemburg: Office for Official Publications of the European Communities

15. Elferts, D., \& Jansons, Ā. (2012). Response of Scots pine radial growth to past and future climate change in Latvia. In: Kḷaviņšs, M., Briede, A. (eds.) Climate change in Latvia and adaptation to it (134 - 145). Rīga: University of Latvia.

16. Fenton, N.J., Frego, K.A., \& Sims, M.R. (2003). Changes in forest floor bryophyte (moss and liverwort) communities 4 years after forest harvest. Canadian Journal of Botany, 81(7), 714 - 731. DOI: 10.1139/ b03-063.

17. Hannerz, M., \& Hånell, B. (1997). Effects on the flora in Norway spruce forests following clearcutting and shelterwood cutting. Forest Ecology and Management, 90(1), 29 - 49. DOI: 10.1016/S03781127(96)03858-3.

18. Häring, T., Reger, B., Ewald, J., Hothorn, T., \& Schröder, B. (2013). Predicting Ellenberg's soil moisture indicator value in the Bavarian Alps using additive georegression. Applied Vegetation Science, 16: $110-$ 121. DOI: 10.1111/j.1654-109X.2012.01210.x.

19. Ignatov, M.S., \& Ignatova, E.A. (2003). Флора мхов средней части Европейской России (Moss Flora of the Middle Part of European Russia). Moscow: Това-рищество научных изданий КМК. (in Russian). 
20. Jansons, Ā., Matisons, R., Puriņa, L., Neimane, U., \& Jansons, J. (2015a). Relationships between climatic variables and tree-ring width of European beech and European larch growing outside of their natural distribution area. Silva Fennica, 49(1). DOI: 10.14214/sf.1255.

21. Jansons, Ā., Matisons, R., Zadiņa, M., Sisenis, L., \& Jansons, J. (2015b). The effect of climatic factors on height increment of Scots pine in sites differing by continentality in Latvia. Silva Fennica, 49(3). DOI: 10.14214/sf.1262.

22. Jarvis, S.G., Rowe, E.C., Henrys, P.A., Smart, S.M., Jones, L., \& Garbutt, A. (2016). Empirical realised niche models for British coastal plant species. Journal of Coastal Conservation, 20(2), 107 - 116. DOI: 10.1007/s11852-016-0422-3.

23. Karlsson, C., \& Örlander, G. (2002). Mineral nutrients in needles of Pinus sylvestris seed trees after release cutting and their correlations with cone production and seed weight. Forest Ecology and Management, 166(1 - 3), 183 - 191. DOI: 10.1016/S0378-1127(01)00684-3.

24. Kuusipalo, J. (1985). On the use of tree stand parameters in estimating light conditions below the canopy. Silva Fennica, 19(2), 185 - 196. DOI: 10.14214/sf.a15418.

25. Laura, M., \& Bērziņa, A. (1978). Čiekuru ražas zudumi un pilno sēklu iznākums priežu sēklu plantācijās (Cone yield loss and seed outcome in conifer seed plantations). Mežsaimniecība un Mežrūpniecība, 4, $3-6$. (in Latvian).

26. Lībiete, Z., Lazdiņ̌s, A., Lazdiņa, D., Bārdulis, A., \& Bārdule, A. (2010). Importance of Forest Monitoring and Progress of FutMon (Further Development and Implementation of an EU-level Forest Monitoring System) Project in Latvia. In Solutions on Harmonizing Sustainability and Nature Protection with SocioEconomic Stability, August 19 - 20. (pp. 109 - 115). Valmiera, Latvia: Vidzeme University of Applied Sciences.

27. Lindner, M., Maroschek, M., Netherer, S., Kremer, A., Barbati, A., Garcia-Gonzalo, J., Seidl, R., Delzon, S., Corona, P., Kolström, M., Lexer, M.J., \& Marchetti, M. (2010). Climate change impacts, adaptive capacity, and vulnerability of European forest ecosystems. Forest Ecology and Management, 259(4). 698 - 709. DOI: 10.1016/j.foreco.2009.09.023.

28. Matisons, R., Jansons, J., Katrevičs, J., \& Jansons, Ā. (2015). Relation of tree-ring width and earlywood vessel size of alien Quercus rubra L. with climatic factors in Latvia. Silva Fennica, 49(4). DOI: 10.14214/ sf.1391.

29. Neimane, U., Vaišl̦a, M., Džeriņa, B., Puriņš, M., \& Jansons, Ā. (2014). Čiekuru un sēklu parametru novērtējums parastās priedes (Pinus sylvestris L.) sēklu plantācijās (Assessment of cone and seed parameters in Scots pine (Pinus sylvestris L.) plantations). Mežzinātne 61(28), 136 - 152. (in Latvian).

30. Nordin, A., Strengbom, J., Witzell, J., Näsholm, T., \& Ericson, L. (2005). Nitrogen Deposition and the Biodiversity of Boreal Forests: Implications for the Nitrogen Critical Load. AMBIO: A Journal of the Human Environment, 34(1), 20 - 24. DOI: 10.1639/0044-7447(2005)034[0020:NDATBO]2.0.CO;2.

31. Nuamah, C. (2017). Understanding Ellenberg's Indicator Values. Retrieved February 1, 2017, from: https:// owlcation.com/stem/Understanding-Ellenberg-Indicator-Values-For-Beginners.

32. Palviainen, M., Finér, L., Mannerkoski, H., Piirainen, S., \& Starr, M. (2005). Responses of ground vegetation species to clear-cutting in a boreal forest: aboveground biomass and nutrient contents during the first 7 years. Ecological Research, 20(6), 652 - 660. DOI: 10.1007/s11284-005-0078-1.

33. Puriņa, L., Neimane, U., Baumane, A., Katrevičs, J., \& Jansons, Ā. (2014). Parastās priedes (Pinus sylvestris L.) pluskoku stumbra kvalitāte (Stem quality of Scots pine (Pinus sylvestris L.)). Mežzinātne 28(61), 108 - 121. (in Latvian).

34. Roberts, M.R., \& Zhu, L. (2002). Early response of the herbaceous layer to harvesting in a mixed coniferous-deciduous forest in New Brunswick, Canada. Forest Ecology and Management, 155(1 - 3), 17 - 31. DOI: 10.1016/S0378-1127(01)00544-8.

35. Sarvas, R. (1962). Investigation on the flowering and seed crop of Pinus sylvestris. Communicationes Instituti Forestalis Fenniae 53.4., 198.

36. Sürmen, B., Kutbay, H.G., Kiliç, D.D., Huseyinova, R., \& Kilinç, M. (2014). Ellenberg's indicator values for soil nitrogen concentration and $\mathrm{pH}$ in selected swamp forests in the Central Black Sea region of Turkey. Turkish Journal of Botany, 38(5), 883 - 895. DOI: 10.3906/bot-1311-43.

37. Szymura, T.H., Szymura, M., \& Macioł, A. (2014). Bioindication with Ellenberg's indicator values: A comparison with measured parameters in Central European oak forests. Ecological Indicators, 46, 495 503. DOI: 10.1016/j.ecolind.2014.07.013.

38. Šēnhofa, S., Zeps, M., Matisons, R., Smilga, J., Lazdina, D., \& Jansons, Ā. (2016). Effect of climatic factors on tree-ring width of Populus hybrids in Latvia. Silva Fennica, 50(1). DOI: 10.14214/sf.1442. 
39. Ter Braak, C.J.F., \& Barendregt, L.G. (1986). Weighted averaging of species indicator values: Its efficiency in environmental calibration. Mathematical Biosciences, 78(1), pp. 57 - 72. DOI: 10.1016/00255564(86)90031-3.

40. Zemkopības ministrija (2017). Meža apsaimniekošana (Forest management). Retrieved January 26, 2017, from: http://www.vmd.gov.lv/valsts-meza-dienests/statiskas-lapas/-meza-apsaimniekosana-?nid= 1472\#jump. (in Latvian).

41. Zviedre, A. (1985). Priedes un egles sēklu saimniecība Latvijas PSR (Pine and spruce seed farm in Latvian SSR). Apskats. Rīga: LatZTIZPI. (in Latvian). 